\title{
The Life History of Desmotrichum undulatum (Phaeophyceae) and its Regulation by Temperature and Light Conditions
}

\author{
H. Rietema and C. van den Hoek
}

Department of Systematic Botany, Biological Centre of the University, P. O. Box 14, 9750 AA Haren (Groningen). The Netherlands

\begin{abstract}
Plurizoids of Desmotrichum undulatum (J. Ag.) Reinke, grow into microthalli bearing macrothalli under a wide range of temperature $\left(4^{\circ}-30^{\circ} \mathrm{C}\right.$ ) and light conditions: short day (SD) 1000, 2000, 4000 Lux; long day (LD) 500, 1000, 2000 Lux. At $35^{\circ} \mathrm{C}$ microthalli die. It is mainly the temperature which modifies the morphological expression of the macrothallus: (1) Higher temperatures ( $\mathrm{ca} 20^{\circ}-30^{\circ} \mathrm{C}$ ) support the development of uniseriate macrothalli; lower temperatures (ca $4^{\circ}-16^{\circ} \mathrm{C}$ ) of pluriseriate ribbon-like thalli; and intermediate temperatures $\left(\mathrm{ca} 16^{\circ}-20^{\circ} \mathrm{C}\right.$ ) of proximally pluriseriate and distally uniseriate macrothalli. These morphological expressions form a graded series. (2) Higher temperatures promote the growth rate of macrothalli; the rapid growth is soon overtaken by intense zoidogeneses which ends the vegetative growth of very small macrothalli. (3) Temperature influences the time span before the onset of zoidogenesis; the time span varies from ca 1 week at $20^{\circ} \mathrm{C}$ to ca 13 weeks at $4{ }^{\circ} \mathrm{C}$. The result is that at lower temperatures $\left(4^{\circ}-12^{\circ} \mathrm{C}\right)$ the final macrothalli size is much larger than at higher temperatures, notwithstanding a lower growth rate. Under short-day conditions the onset of zoidogenesis is advanced, particularly so at lower temperatures. Therefore, the largest macrothalli are formed at lower temperatures and under long-day conditions; this corresponds to late spring in nature. Maximum macrothalli length in culture (at $8^{\circ} \mathrm{C}$ ) was ca $60 \mathrm{~cm}$. Such macrothalli conform to the description of Punctaria latifolia also in other respects. Therefore D. undulatum (including D. balticum and $D$. scopulorum) is thought to be synonymous with $P$. latifolia. The seasonal occurrence of macrothalli (winter-spring) and the geographic distribution are in accordance with results obtained in culture
\end{abstract}

\section{INTRODUCTION}

The life history of Desmotrichum undulatum (J. Ag.) Reinke comprises an erect macrothallus phase which sprouts directly from a creeping and filamentous microthallus phase (Kylin, 1933; Rhodes, 1970a). Both microthallus and macrothallus produce plurilocular zoidangia; after release the plurizoids grow, without fusion, into new microthalli. According to Rhodes (1970a) initiation of macrothalli from microthalli occurs only at lower, not at higher temperatures (he cultured at $6{ }^{\circ} \mathrm{C}$ and $21{ }^{\circ} \mathrm{C}$ ). In a comparable way the development of the macrothallus from the microthallus was reported to depend on low temperature $\left(12^{\circ} \mathrm{C}\right)$ in Myriotrichia clavaeformis Harv. (Loiseaux, 1969). A combination of low temperature and short-day conditions appears to promote the development of macrothalli from crustose microthalli in Petalonia fascia (O. F. Müll.) Kuntze and Scytosiphon lomentaria (Lyngb.) Link (for review, see Wynne and Loiseaux, 1976).
These few examples suggest that maritime temperature and light conditions (expressed as daily light dose and/or daylength) modulate the morphological expressions of algae with heteromorphic life histories in such a way that they can explain the seasonal 'wax and wane' of these expressions, and possibly also their geographic distribution. In a recent review van den Hoek (1979) argues that, on the basis of distribution patterns, phytogeographic boundaries of benthic marine algal species seem to be primarily set by temperature conditions, not by light conditions; within temperature-set boundaries the morphological expressions are probably modified by temperature and often also light conditions. One example of how this might work was given by Breeman (1979). In the warmtemperate red alga Acrosymphyton purpuriferum (J. Ag.) Sjöst. the northern boundary is set by a minimum summer temperature (ca $17^{\circ} \mathrm{C}$ ) necessary for the formation of gametangia in the macrothallus; the southern boundary, by a maximum winter temperature (ca $18^{\circ} \mathrm{C}$ ) still permitting the formation of tetrasporangia 
by the microthallus. Within these temperature limits short daylength triggers the maturation of the tetrasporophyte.

It is the aim of the present study to analyse the combined influence of a wide range of temperature and light conditions on the life history of Desmotrichum undulatum, in particular on the conversion of microthallus to macrothallus, and to relate, if possible, the results to the species seasonal occurrence and geographic distribution. D. undulatum is particularly well suited for this type of study because of the absence of complicating sexual processes. Rhodes (1970a) investigated only the influence of 2 different temperatures $\left(6^{\circ}\right.$ and $21^{\circ} \mathrm{C}$ ); this provided a preliminary insight into the influence of this factor.

\section{MATERIAL AND METHODS}

Desmotrichum undulatum (J. Ag.) Reinke was collected in August 1978 in a large, protected tide-pool ('de Kom') at the south coast of the Wadden Island Terschelling, The Netherlands. The ca $1 \mathrm{~cm}$ high plants were part of a dense epiphytic growth on Petalonia fascia and Scytosiphon lomentaria (together with Ectocarpus sp. and Giffordia sp.). Only plurilocular (not unilocular) zoidangia were present.

Unialgal cultures were established from plurispores. These were massively released after transfer of fertile plants to a higher temperature and light intensity. Spores were isolated by pipetting and they were allowed to settle in the dark on glass squares $(25 \mathrm{~mm} \times$ $25 \mathrm{~mm}$ ) cut from microscopic slides which covered the bottom of Petri dishes with a diameter of $17 \mathrm{~cm}$. Such glass squares, after being seeded, from dilute suspensions of zoospores, with roughly equal numbers of zoospores, were used for experimental purposes. Petri dishes each with one seeded glass square were exposed to the different temperature and light regimes given in Figure 1 and, in addition to $35{ }^{\circ} \mathrm{C}$ long-day (LD) conditions (1000 Lux and 500 Lux). Long-day condition (LD) in Figure 1 is defined as $16 \mathrm{~h} \mathrm{light} \mathrm{and} 8$ $\mathrm{h}$ dark (16: $\overline{8})$, short-day conditions as $8 \mathrm{~h}$ light and $16 \mathrm{~h}$ $\operatorname{dark}(8: \overline{16})$.

In the first experiment (Exp. a) the seeded glass squares were precultured during $12 \mathrm{~d}$ at $12^{\circ} \mathrm{C}$ and 2000 Lux and subsequently transferred to experimental conditions. The spores had grown into young microthalli. Growth and reproduction of these cultures were observed at 2-week intervals during a period of 12 weeks.

In the second experiment (Exp. b) the seeded glass squares were transferred to experimental conditions immediately after spore settlement.

In the third experiment (Exp. c) cut-off macrothalli with a maximum length of $2 \mathrm{~mm}$ were transferred to the experimental conditions given in Figure 8. One macrothallus was cultured separately in one Petri dish containing culture medium. The culture medium was renewed by transferring the macrothalli to new Petri dishes with new culture medium so that young microthalli grown from released zoids were left behind. Growth and reproduction of these macrothalli were observed at weekly intervals.

For all experiments Petri dishes with a diameter of $10 \mathrm{~cm}$ were used, containing a Provasoli medium (Provasoli, 1968), which was renewed at first after 4 weeks, then once every 2 weeks.

The cultures were kept in controlled-environment incubators (Fridina). Light was provided by cool white fluorescent tubes (Philips TL 34) and measured with an AEG Lux meter. Different illumination levels were obtained by varying the distance to the light source or by interposing one or more layers of transparent paper. The temperature values given varied not more than \pm $2 \mathrm{C}^{\circ}$, daylength values not more than $\pm 30 \mathrm{~min}$, light values not more than $\pm 10 \%$.

\section{RESULTS}

\section{Experiment a}

The results of Experiment a are summarized in Figures 1-5. All glass squares were covered by more or less well-developed macrothalli; under each set of culture conditions several macrothalli sprouted from each of these microthalli after 2 weeks. Figure 6 and Figure $7 \mathrm{a}, \mathrm{c}, \mathrm{d}$ realistically illustrate some of these cultures. In Figures 1-5 the state of the culture kept under one set of experimental conditions during a given period is diagrammatically summarized: the largest and smallest macrothallus, and the largest and smallest microthallus on the glass square are pictured according to scale. Only the circumference of the microthallus is illustrated. Spiral twisting of the macrothallus is omitted. The occurrence of plurilocular zoidangia on the thallus is indicated, but they are not drawn to scale (their size is exaggerated). In this way the size ranges of both microthalli and macrothalli exposed to one set of conditions at a given moment are presented. This approach was chosen (instead of determining mean sizes) in order to restrict to a minimum the time necessary for inspection and measuring (by means of the drawing apparatus of the binocular dissection microscope) and to prevent damage to the culture. Microthalli transferred to $35^{\circ} \mathrm{C}$ died within 2 weeks; therefore this temperature is not mentioned in Figures 1-5.

As seen in Figures 1-5, the morphology of macrothalli varies continuously with temperature - higher temperatures favouring the growth of partly-to- 


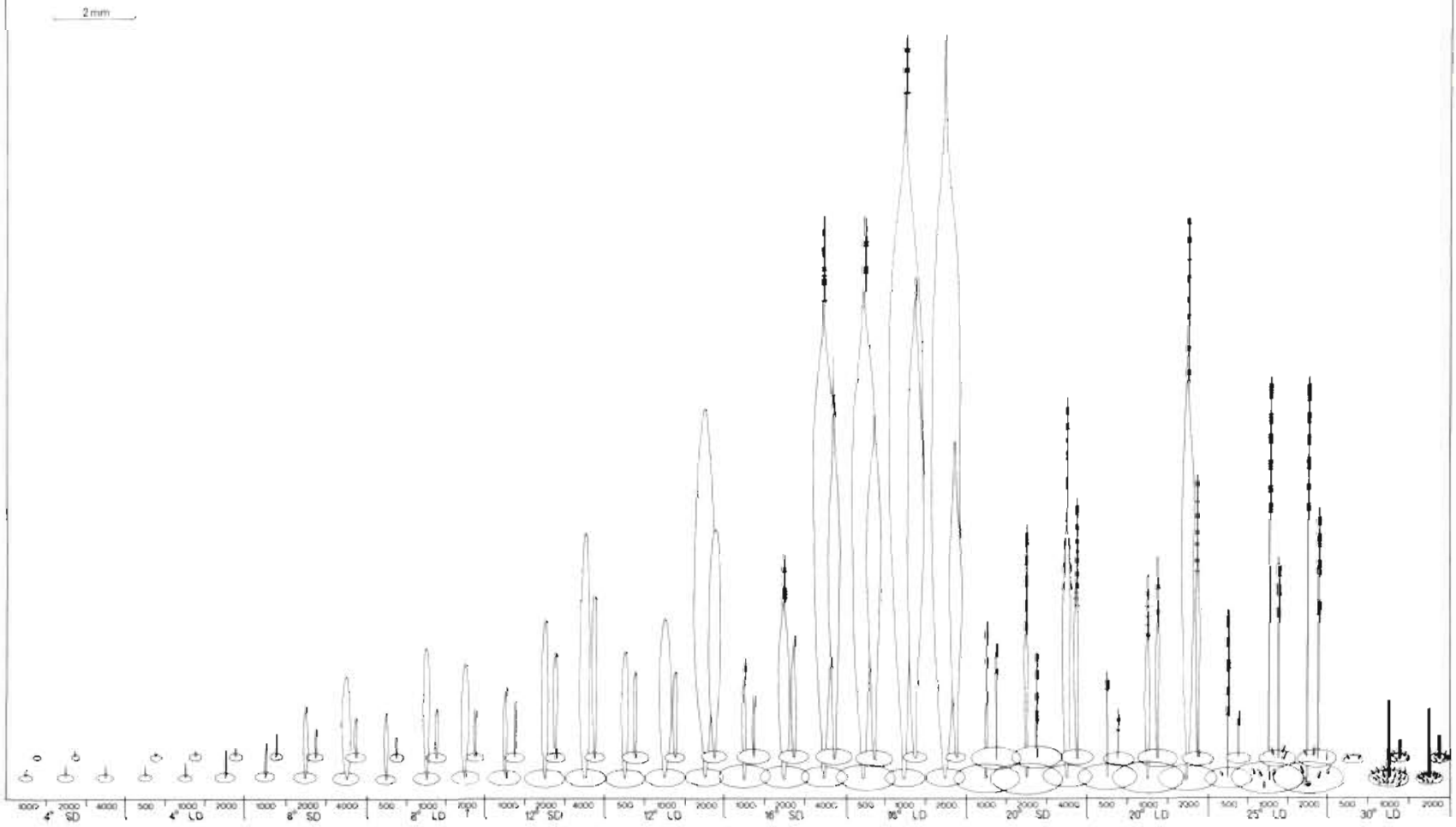

Fig. 1. Desmotrichum undulatum. Growth and reproduction under different temperature and light conditions after 2 weeks. LD $=$ long-day conditions ( $16 \mathrm{~h}$ light, $8 \mathrm{~h}$ dark); $\mathrm{SD}=$ short-day conditions ( $8 \mathrm{~h}$ light, $16 \mathrm{~h}$ dark). For each combination of day length and temperature 3 illumination levels (in Lux) are given. Size ranges of macrothalli and microthalli and the occurrence of plurilocular zoidangia are indicated for each experimental condition

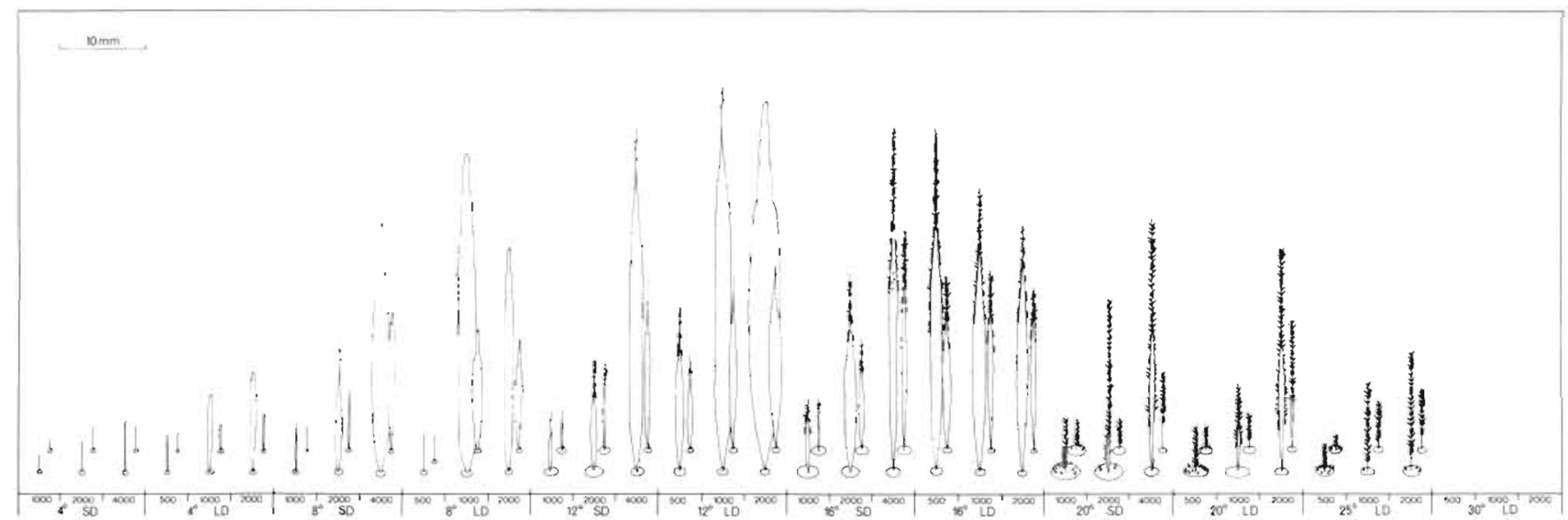

Fig. 2. Desmotrichum undulatum. Growth and reproduction under different temperature and light conditions after 4 weeks. For further explanation see legend to Figure 1

entirely uniseriate macrothalli, lower temperatures the growth of partly-to-entirely pluriseriate, ribbon-like macrothalli (Fig. $7 \mathrm{C}, \mathrm{i}$ ). In particular, uniseriate and narrow pluriseriate macrothalli showed considerable spiralling and even 'cable rolling' (Fig. 7a). Older fertile pluriseriate macrothalli also revealed intense spiralling and a bubbled surface (Fig. 7d).

Very young stages of pluriseriate macrothalli appeared to be uniseriate (Fig. $7 \mathrm{~h}, \mathrm{j}$ ) but they became pluriseriate very soon after initiation (Fig. 7i, j). Cell divisions were intercalary in both pluriseriate (Fig. 7i) and uniseriate (Fig. $7 \mathrm{~g}$ ) macrothalli and cell-families could be distinguished as they were delimited by distinct constrictions (Fig. 7i, arrows). Filamentous microthalli grew only by apical cell divisions. Their radiating filaments showed unilateral curvature (Fig. 7b). 
Macrothalli were primarily attached to the substratum by the microthalli from which they arose, but at a later stage rhizoids growing from the basal cells of the macrothallus provided a secondary anchorage (Fig. 7i). In older thalli these rhizoids often completely overgrew the microthallus. Islands of living cells in old, moribund macrothalli often produced rhizoids which finally grew into inextricable tangles.

Phaeophycean hairs with typical basal sheaths and basal meristems occurred on both macrothalli and microthalli. Along the margins of macrothalli they were mostly solitary though often placed in close proximity (Fig. 7i, m); single hair, as well as bundles of hair, arose from the laminae of pluriseriate thalli - bundles mainly from larger and older thalli (Fig. 7k). Hairs died off on old macrothalli disintegrating by zoidogenesis. Macrothalli were characteristically terminated by an apical hair (Fig. 7g, i, j).

Formation of plurilocular zoidangia in macrothalli appeared to proceed from apex to basis (Fig, $7 \mathrm{a}, \mathrm{c}, \mathrm{d}$ ). The zoidangia were partly embedded in the macrothallus from which they protruded only a little (Fig. $7 \mathrm{e}, \mathrm{f}, \mathrm{m})$. At the lowest temperatures $\left(4^{\circ} \mathrm{C}, 8^{\circ} \mathrm{C}\right)$ they were almost entirely embedded in vegetative tissue. Old macrothalli previously matured by such embedded zoidangia produced later large, lanceolate plurilocular zoidangia. Such lanceolate, sometimes branched zoidangia were also borne by microthalli (Fig. 7 g).

Figure 1 shows that after 2 weeks macrothalli had developed from microthalli under all conditions tested (temperatures varying from $44^{\circ}-30^{\circ} \mathrm{C}$ ), except at $30^{\circ} \mathrm{C}$ LD 500 Lux, where only a new, young generation of microthalli was present. Growth of macrothalli was clearly temperature- and light dependent, the longest macrothalli having grown at $16{ }^{\circ} \mathrm{C}$, while at each separate temperature tested, the shortest macrothalli had grown at the lowest light doses offered. The largest microthalli, however, were obtained at $20^{\circ}$ and $25{ }^{\circ} \mathrm{C}$. High temperature apparently promoted the formation of plurilocular zoidangia. Zoidangia formation was most intense on both micro- and macrothalli at 30 ${ }^{\circ} \mathrm{C}$; macrothalli were here in the process of complete disintegration by zoidogenesis. Somewhat less profuse formation of zoidangia had taken place on both microand macrothalli at $25{ }^{\circ} \mathrm{C}$. Profuse formation of zoidangia occurred only on macrothalli (and not on microthalli) of $20^{\circ} \mathrm{C}$ cultures; in the apical regions of $16^{\circ} \mathrm{C}$ cultures, formation of zoidangia had apparently just started.

When comparing 4 week old cultures (Fig. 2) and 6 week old cultures (Fig. 3) with 2 week old cultures (Fig. 1) part of the results seem, at first glance to be contradictory. (Note the scale difference between Fig. 1 and Figs 2-5!). In Figure 1, $16{ }^{\circ} \mathrm{C}$ seems to be the optimum temperature for macrothallus growth; in Figure $2,12^{\circ} \mathrm{C}$; in Figure $3,8^{\circ} \mathrm{C}$.

A comparison of Figure 1 with Figures 2 and 3 also shows that, in the course of time, zoidogenesis had progressed from higher to lower temperatures. After 4 weeks at $30^{\circ} \mathrm{C}$, the original micro- and macrothalli had been completely disintegrated by zoidogenesis and

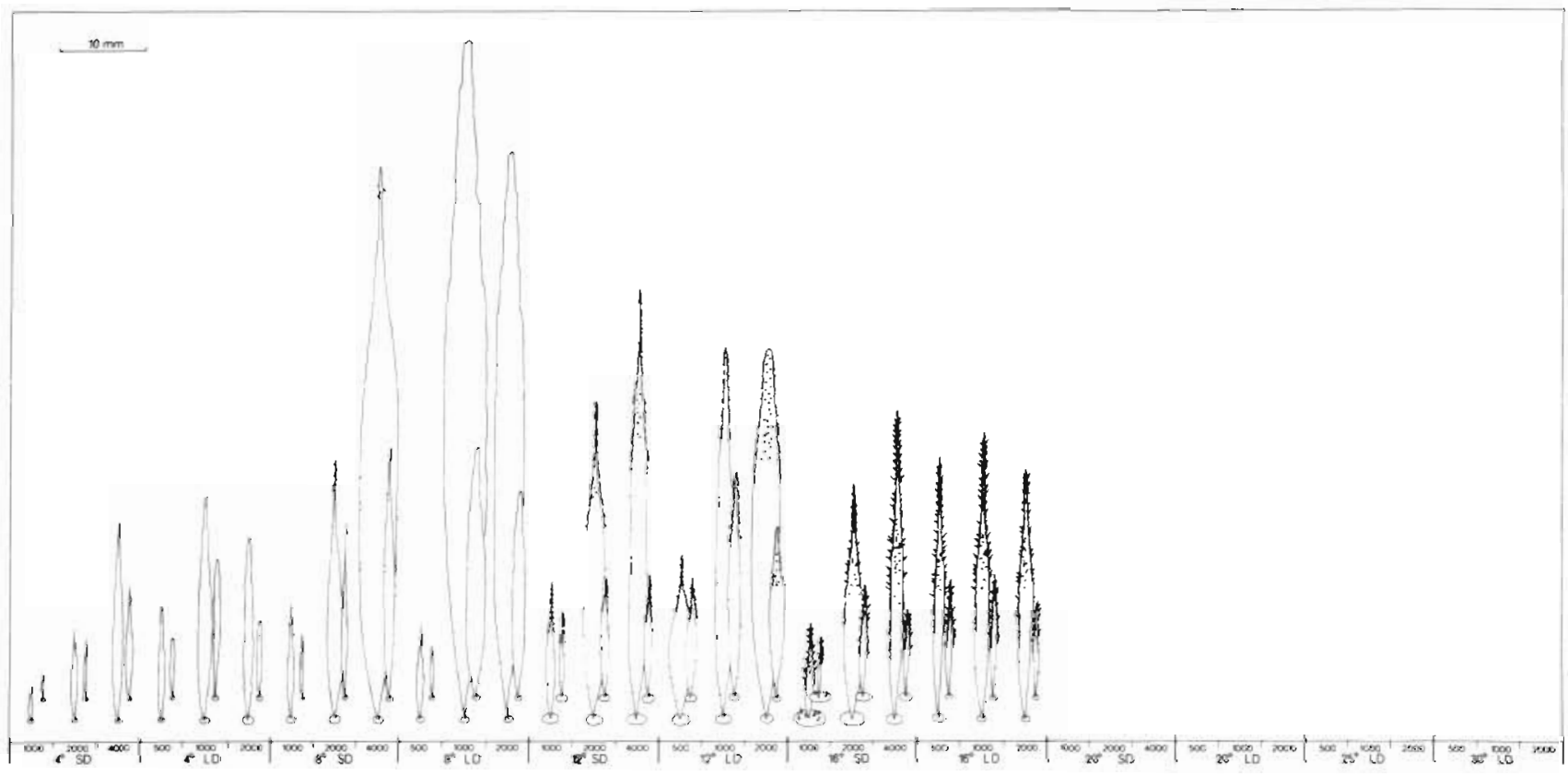

Fig. 3. Desmotrichum undulatum. Growth and reproduction under different temperature and light conditions after 6 weeks. For further explanation see legend to Figure 1 


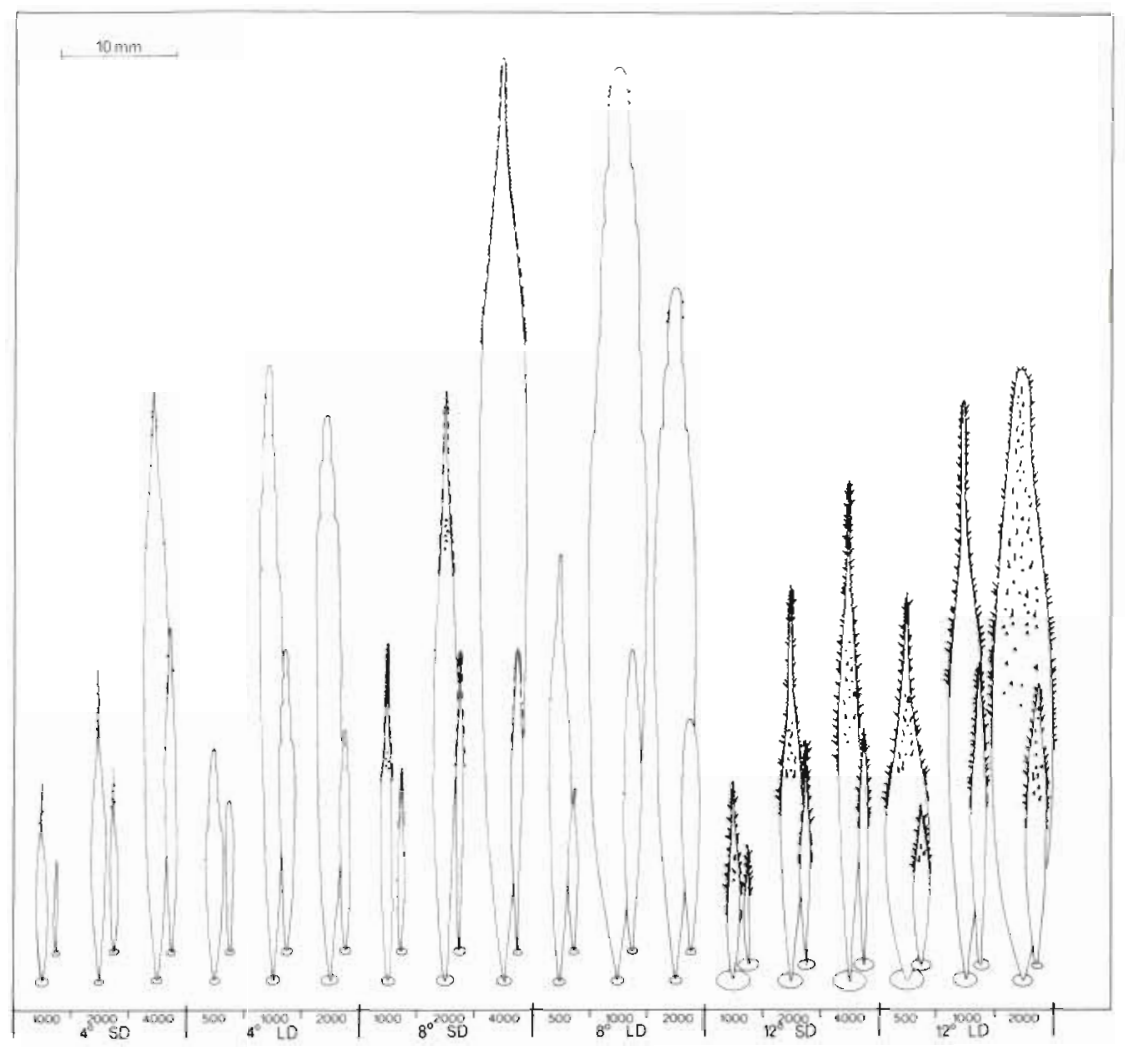

Fig. 4. Desmotrichum undulatum. Growth and reproduction under different temperature and light conditions after 8 weeks. For further explanation see legend to Figure 1

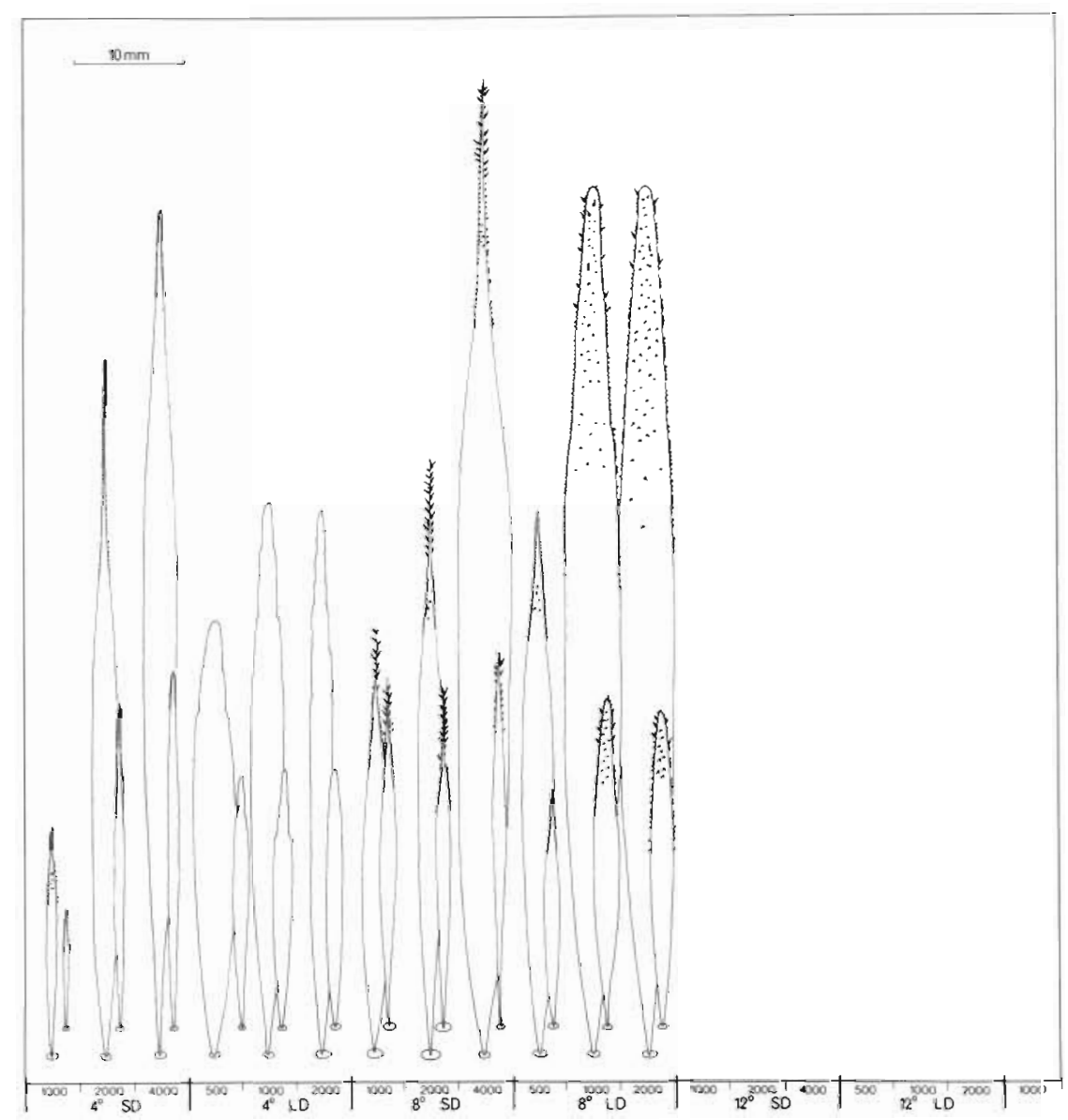

Fig. 5. Desmotrichum undulatum. Growth and reproduction under different temperature and light conditions after 12 weeks. For further explanation see legend to Figure 1 


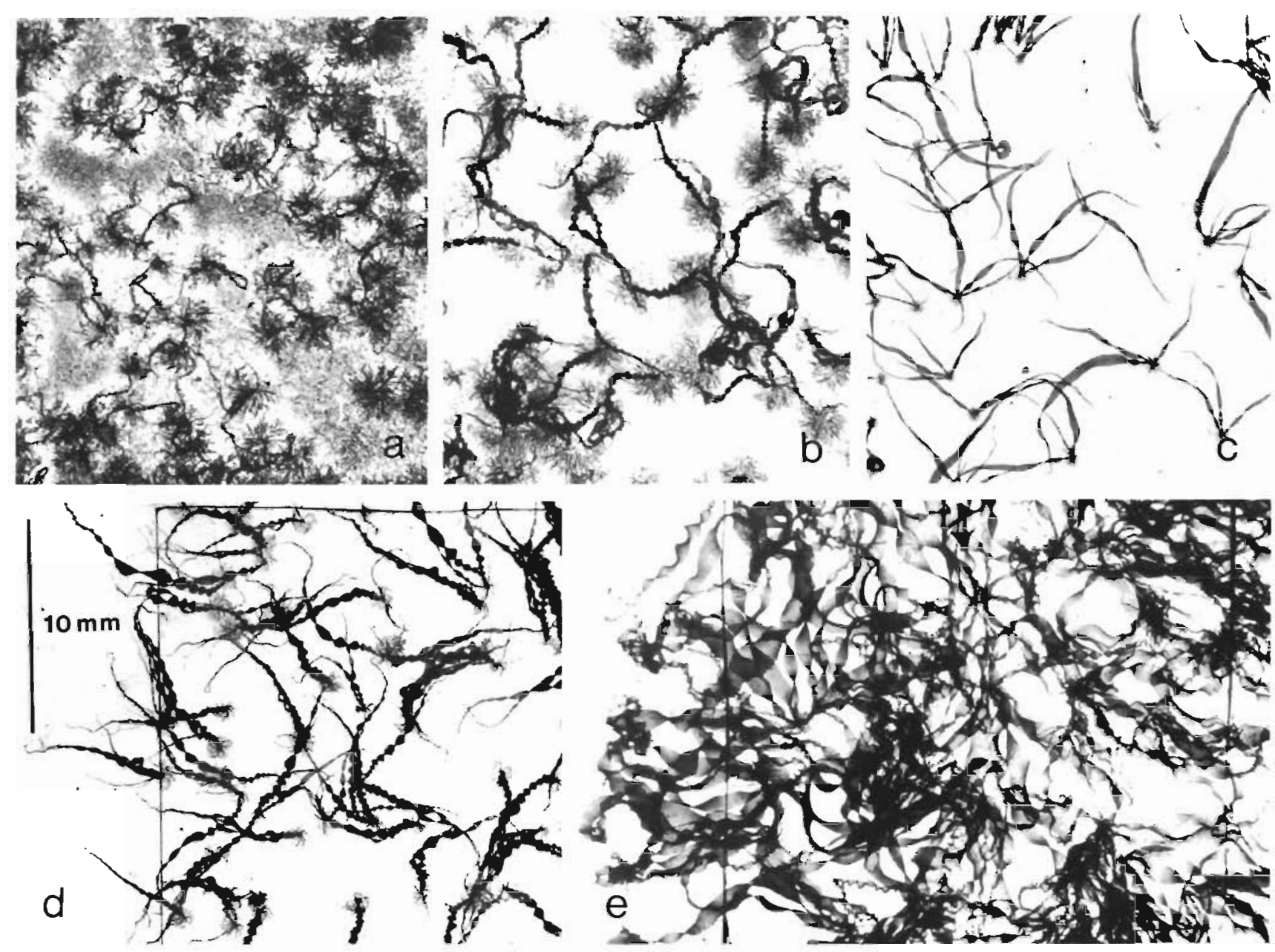

Fig. 6. Desmotrichum undulatum. Photographs of 4 week old plants (illustrated diagrammatically in Fig. 2 ); (a) $20^{\circ} \mathrm{C}, \mathrm{SD}, 1000$ Lux; (b) $16^{\circ} \mathrm{C}, \mathrm{SD}, 1000$ Lux; (c) $8{ }^{\circ} \mathrm{C}, \mathrm{SD}, 1000 \mathrm{Lux}$; (d) $12{ }^{\circ} \mathrm{C}, \mathrm{SD}, 1000 \mathrm{Lux}$ ( (e) $12{ }^{\circ} \mathrm{C}, \mathrm{LD}, 500 \mathrm{Lux}$

the bottoms of the Petri dishes were covered by a profusion of second-generation microthalli bearing lanceolate zoidangia. In the $25^{\circ}$ and $20^{\circ} \mathrm{C}$ cultures, both micro- and macrothalli were in the process of disintegration by zoidogenesis and the bottoms of the Petri dishes were covered by a profuse tangle of a second generation of microthalli (cf. Fig. 6a: the grey patches among the microthalli are tangles of newgeneration microthalli). Measurements were impossible on such disintegrated cultures composed of large numbers of more or less entangled microthalli of the second generation; therefore such measurements were discontinued. After 4 weeks, zoidogenesis of macrothalli had progressed to macrothalli of $12^{\circ} \mathrm{C}$ cultures; after 6 weeks microthalli of $16{ }^{\circ} \mathrm{C}$ cultures had also developed zoidangia, and zoidogenesis of macrothalli had progressed to $8{ }^{\circ} \mathrm{C}$ (short day) cultures. Zoidogenesis by microthalli was not observed at temperatures below $16{ }^{\circ} \mathrm{C}$. It is likely that the production of plurizoids diminishes, and in the end stops vegetative growth of the macrothalli, as the photosynthetic effort can be used either for the production of new vegetative cells or reproductive cells. This is particularly clear when zoidogenesis results in the disintegration of the thallus.

This phenomenon explains why 2 week old cultures, 4 week old cultures and 6 week old cultures seem to have different temperature optima for growth. Macrothallus growth at $16{ }^{\circ} \mathrm{C}$ was, in the first 2 weeks, apparently more rapid than at lower temperatures (Fig. 1). At that moment the beginning (Fig. 1), and in the next 2 weeks intensely progressing (Fig. 2) zoidogenesis, slowed down and stopped vegetative growth so that the macrothalli had reached their maximum length after about 4 weeks. Later (in 6-8 week old cultures) intense sporulation resulted in the disin tegration of the macrothalli (which could consequently no longer be measured).

In the same way the somewhat more slowly-growing $12{ }^{\circ} \mathrm{C}$ macrothalli had reached their maximum length after about 4 weeks (Fig. 2) and started to disintegrate by intense zoidogenesis after 8 weeks (Fig. 4). 


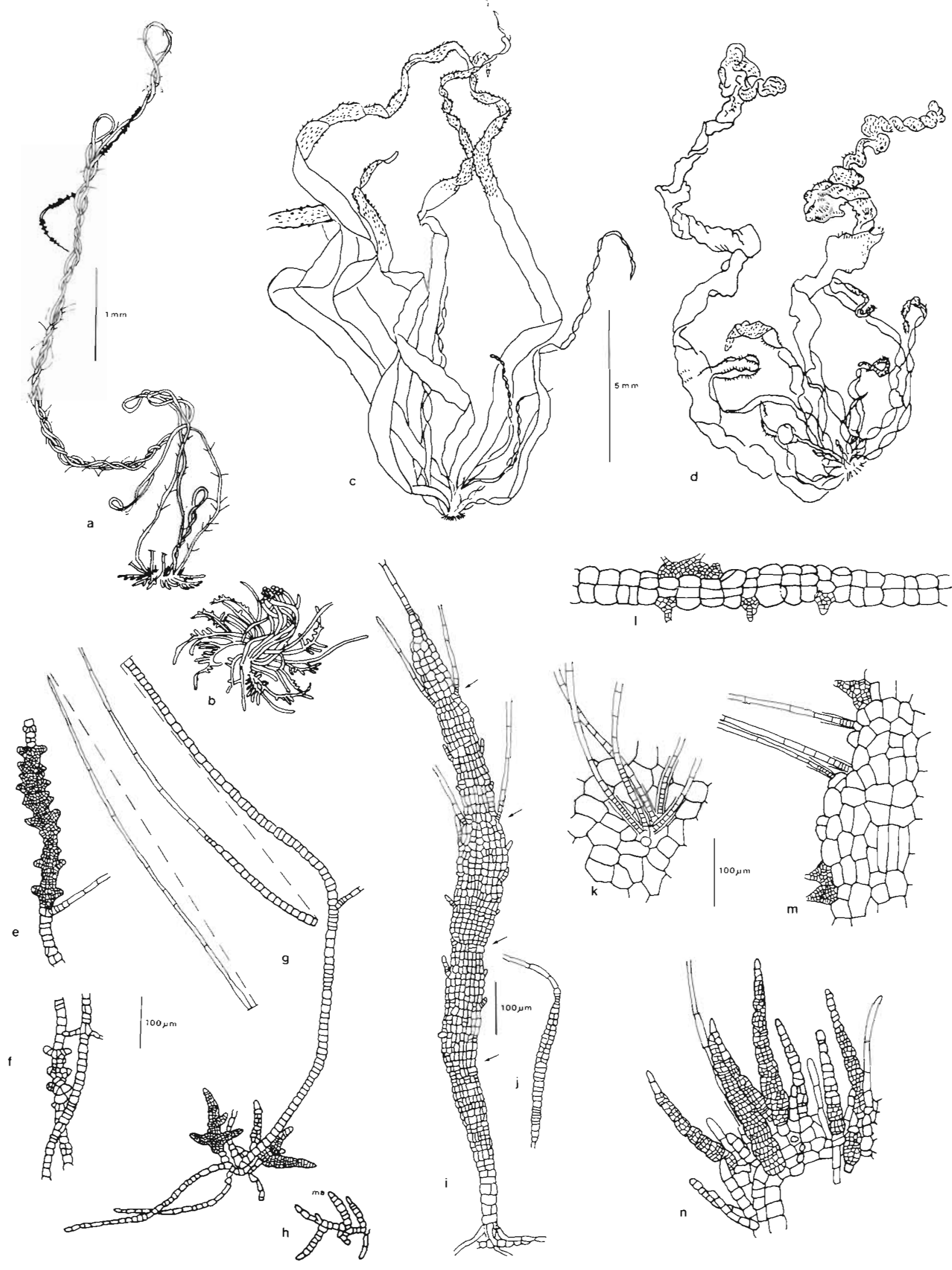

Fig. 7. Desmotrichum undulatum. (a) Spirally twisted, entangled uniseriate macrothalli sprouting from microthallus (2 week old plant; $25^{\circ} \mathrm{C}, \mathrm{LD}, 2000$ Lux); (b) same microthallus in surface view; (c) pluriseriate macrothalli with spiralling pluriseriate macrothalli - with distal zoidangia (dots) - sprouting from micrathallus (4 week old plant; $16{ }^{\circ} \mathrm{C}, \mathrm{LD}, 2000$ Lux); (d) pluriseriate macrothalli with spiralling, bubbled, distally fertile macrothalli sprouting from one microthallus $\left(6\right.$ week old plant; $12{ }^{\circ} \mathrm{C}, \mathrm{LD}$, 2000 Lux). e, f, g, h illustrate details of a: (e) plurilocular zoidangia on uniseriate macrothallus; (f) 2 parts of same macrothallus grown around each other and with one end growing downwards; $(\mathrm{g})$ non-fertile microthallus sprouting from fertile macrothallus; (h) young macrothalli (ma) sprouting from microthallus; (i, j) pluriseriate macrothalli sprouting from microthallus with rhizoids sprouting from the base of the largest macrothallus; $\mathrm{k}, 1, \mathrm{~m}$ illustrate details of a pluriseriate macrothallus $\left(8\right.$ week old plant; $8{ }^{\circ} \mathrm{C}$, SD, 2000 Lux): (k) a bundle of phaeophycean hairs on the lamina; (1) cross-section of the macrothallus with partly embedded plurilocular zoidangia; (m) margin with partly embedded zoidangia and phaeophycean hairs; (n) lanceolate plurilocular zoidangia on heavily fertile macrothallus ( 4 week old plant; $20^{\circ} \mathrm{C}, \mathrm{LD}, 2000 \mathrm{Lux}$ ) 


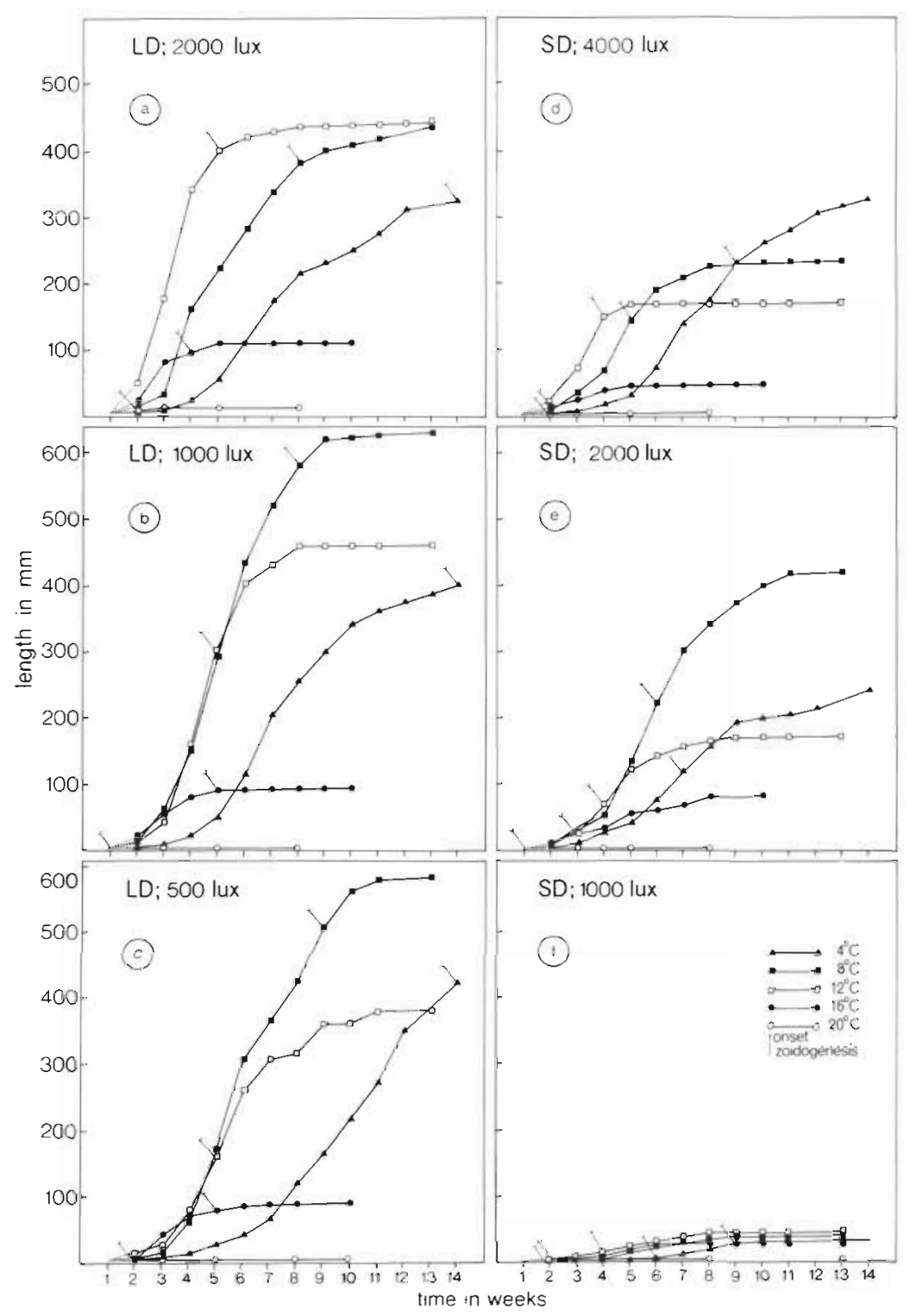

Fig. 8. Desmotrichum undulatum. Growth and reproduction (onset of zoidogenesis) of macrothalli under different light and temperature conditions. Each curve represents the increase in length of one individual macrothallus grown separately in a $10 \mathrm{~cm}$ Petri dish; culture medium renewed once every 2 weeks. The original macrothalli had a maximum length of $2 \mathrm{~mm}$

The $8{ }^{\circ} \mathrm{C}$ macrothalli, exhibiting still slower growth, reached in this way their maximum length after 6 weeks; and the $4{ }^{\circ} \mathrm{C}$ macrothalli after 12 weeks. The comparatively late onset of zoidogenesis in the $8^{\circ}$ and $4^{\circ} \mathrm{C}$ macrothalli permitted these to attain maximum lengths largely surpassing those of $12^{\circ}$ and $16^{\circ} \mathrm{C}$ macrothalli (compare Figs 5, 4 with Fig. 2).

The above consideration raises the question whether or not the initial vegetative growth of the $20^{\circ}, 25^{\circ}$ and $30^{\circ} \mathrm{C}$ macrothalli, which came to an early end by the early onset of intense zoidogenesis, have a more rapid growth than that of $16^{\circ} \mathrm{C}$ macrothalli. The occurrence of the largest microthalli at $20^{\circ}$ and $25^{\circ} \mathrm{C}$ after 2 weeks suggests that this possibility should not be excluded.
Figures 1-5 clearly show the profound influence of temperature on growth, form and zoidogenesis of macrothalli and microthalli. Daylength also seems to have an influence: under short-day conditions the onset of zoidogenesis was advanced (Fig. $2: 8^{\circ} \mathrm{C}, \mathrm{SD}, 2000 \mathrm{Lux}$; Fig. 3: $8{ }^{\circ} \mathrm{C}, \mathrm{SD}$; Fig. $4: 4{ }^{\circ} \mathrm{C}, \mathrm{SD}$ ); consequently, the final sizes of macrothalli were smaller.

\section{Experiment b}

The results of Experiment $b$ were similar to those of Experiment a and will therefore not be treated here in detail. The only difference was that no macrothalli 
developed at the lowest light doses in the $20^{\circ}$ and $25^{\circ} \mathrm{C}$ series.

\section{Experiment $\mathbf{c}$}

Figure $8 \mathrm{a}, \mathrm{b}, \mathrm{c}, \mathrm{d}$ and e shows that (under all light regimes, except $1000 \mathrm{~L}, \mathrm{SD}$ ) the sequence in which the cultures reached their maximum lengths at various temperatures is: $20^{\circ} \rightarrow 16^{\circ} \rightarrow 12^{\circ} \rightarrow 8^{\circ} \rightarrow 4^{\circ} \mathrm{C}$. The cultures at $1000 \mathrm{~L}, \mathrm{SD}$ (Fig. 8f) grew too slowly to reveal sufficiently distinct differences. This sequence is identical with that in which cultures under all light regimes started zoidogenesis. In most cases the onset of zoidogenesis preceded the levelling off in the growth curves within 2-4 weeks. In these two respects the results of Experiment $c$ were comparable to the results of Experiments a and b. As in Experiments a and $\mathrm{b}$, the maximum lengths attained by the $8^{\circ} \mathrm{C}$ cultures were larger than those of the $12^{\circ}$ and $4{ }^{\circ} \mathrm{C}$ cultures in Figure $8 \mathrm{~b}, \mathrm{c}$ and e. In Figure $8 \mathrm{a}$ maximum lengths of the $12^{\circ} \mathrm{C}$ culture, and in Figure $8 \mathrm{~d}$ maximum length of the $4{ }^{\circ} \mathrm{C}$ culture were largest. These differences cannot be considered statistically significant, because the original macrothalli differed somewhat in size (they had a maximum length of $2 \mathrm{~mm}$ ) and this would be sufficient to explain differences in final size assuming equal growth rates under similar conditions.

Under all light conditions tested (except $1000 \mathrm{~L}, \mathrm{SD}$ ) the $4{ }^{\circ} \mathrm{C}$ growth curves did not yet level off, suggesting higher final maximum sizes than actually attained.

Under short-day conditions the onset of zoidogenesis was distinctly advanced. This was not caused by a lower daily light dose, because in cultures receiving about equal daily light doses and growing at the same temperature the short-day algae revealed a clearly advanced onset of zoidogenesis (compare Fig. 8a with $8 \mathrm{~d} ; 8 \mathrm{~b}$ with $8 \mathrm{e} ; 8 \mathrm{c}$ with $8 \mathrm{f}$ ). Such influence of short-day conditions was also suggested by Experiment a Moreover this advancement of zoidogenesis seems to be independent of illuminance, as suggested by Table 1 (based on Fig. 8 and Figs. 1-5). However, the conspicuous differences in growth rates between $500 \mathrm{~L}, \mathrm{LD}$ cultures and 1000 L, SD cultures (Fig. 8c, f) suggest that the roughly equal daily light doses are not photosynthetically equally efficient and therefore a photosynthetic-mediated effect should not be excluded.

One important difference between the results of Experiment $c$ and those of Experiment $a$ is the fact that the maximum sizes of macrothalli reached in Experiment $c$ are much larger than those reached in Experiment $a$. In the LD-cultures of Experiment $c$, the maximum lengths of macrothalli at $4^{\circ}, 8^{\circ}$ and $12^{\circ} \mathrm{C}$ were about one order of magnitude greater, namely between
300 to $650 \mathrm{~mm}$; in comparable cultures of Experiment a they were only 30 to $90 \mathrm{~mm}$. For the $16^{\circ} \mathrm{C}$ LD cultures these values were $80-100 \mathrm{~mm}$, and $20-35 \mathrm{~mm}$, respectively; for the $20^{\circ} \mathrm{C}$ LD cultures ca $2-10 \mathrm{~mm}$ and 2-25 $\mathrm{mm}$, respectively. Obviously, the $20^{\circ} \mathrm{C}$ macrothalli in Experiment $c$ did not show any appreciable growth after transfer to $20^{\circ} \mathrm{C}$ and started immediately intense zoidogenesis.

This enormous difference in size was not at all parallelled by a difference in the onset of zoidogenesis (Table 1). Apparently onset of zoidogenesis in the development of the macrothallus is not size-dependent.

\section{DISCUSSION AND CONCLUSIONS}

Both the microthallus and macrothallus phase of Desmotrichum undulatum can be formed under a wide range of temperature $\left(4^{\circ}-30^{\circ} \mathrm{C}\right)$ and light conditions (short day, 1000, 2000, 4000 Lux; long day, 500, 1000, 2000 Lux). Only under low illuminance and at high temperatures (long day, $500 \mathrm{Lux}, 30^{\circ}, 25^{\circ}, 20^{\circ} \mathrm{C}$ ) does the formation of macrothalli from microthalli sometimes fail to occur. Also old, crowded cultures containing several generations of microthalli do not, or only rarely, form macrothalli at higher temperatures. Microthalli grow from plurizoids under all conditions tested; an absolute upper limit is set by the lethal temperature of $35{ }^{\circ} \mathrm{C}$; an absolute lower limit for growth and reproduction was not reached in the present experiments. Macrothalli can only arise in the form of shoots with intercalary growth sprouting from apically growing microthalli (Fig. $7 \mathrm{~h}, \mathrm{~g}, \mathrm{i}, \mathrm{j}$ ).

Temperature is the main factor which modulates the morphological expression of the macrothallus: (1) High temperatures support the development of uniseriate macrothalli; low temperatures of pluriseriate, bladeto-ribbon-like macrothalli; intermediate temperatures, of thalli which are distally uniseriate and proximally pluriseriate. These morphological expressions of the macrothallus form a graded series (Fig. 1). Initials of pluriseriate macrothalli start as short uniseriate filaments (Fig. 7h) which, however, soon become pluriseriate (Fig. 7j, i). In contrast to Kylin (1933) and Rosenvinge and Lund's (1947) opinion, mature uniseriate macrothalli (Fig. 7a, e, f) do not represent young stages of pluriseriate macrothalli. However, our results confirm the assumption of these authors that Desmotrichum balticum Küt, Desmotrichum scopulorum Reinke, and $D$. repens Kylin represent uniseriate plants of D. undulatum (J. Ag.) Reinke (Reinke, 1889). (2) High temperatures promote the growth rate of macrothalli. Figure 1 (2 week old cultures) suggests that $16^{\circ} \mathrm{C}$ is the optimum temperature for vegetative mac- 


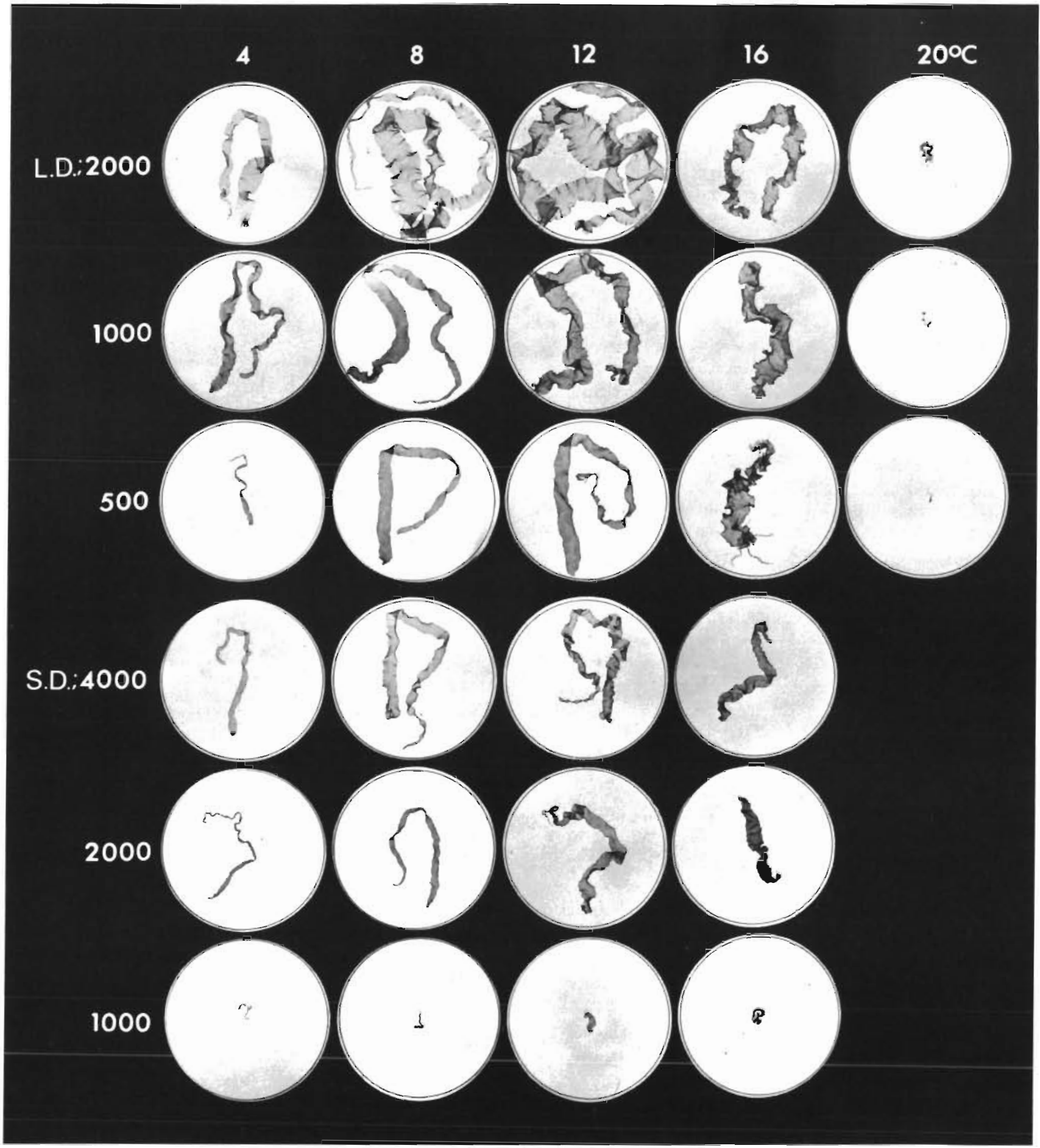

Fig. 9. Desmotrichum undulatum. 5-6 week old macrothalli; their growth is illustrated in Figure 8a-f. Diameter of Petri dishes: $10 \mathrm{~cm}$

rothalli growth, but possibly also $20^{\circ}$ and $25^{\circ} \mathrm{C}$ promote rapid initial growth; this, however, is overtaken very soon (in less than 2 weeks) by intense zoidogenesis putting an end to the growth of macrothalli when still very small. (3) High temperatures promote an ephemeral existence of macrothalli. This is caused by the fact that temperature influences the final macrothallus length by determining, in some way, the time span before the onset of zoidogenesis. The photosynthetic effort of the macrothallus can be used either for the production of new vegetative cells or of reproductive cells. Hence, $0-4$ weeks after the onset of 
Table 1. Desmotrichum undulatum. Onset of zoidogenesis. Data refer to weeks after start of experiment (based on Fig. 8). Bracketed numbers: weeks based on Figure 1-5

\begin{tabular}{|c|c|c|c|c|c|}
\hline Condition & $20^{\circ} \mathrm{C}$ & $16^{\circ} \mathrm{C}$ & $12^{\circ} \mathrm{C}$ & $8^{\circ} \mathrm{C}$ & $4^{\circ} \mathrm{C}$ \\
\hline LD, 500 Lux & $1(<2)$ & $4(2)$ & $4(4)$ & $8(8-12)$ & $13(>12)$ \\
\hline LD, 1000 Lux & $0 \quad(<2)$ & $4(2)$ & $4(4)$ & $7(8)$ & $13(>12)$ \\
\hline LD, 2000 Lux & $1(<2)$ & $3(2-4)$ & $4(4-6)$ & $7(8)$ & $13(12)$ \\
\hline SD, 1000 Lux & $1 \quad(<2)$ & $1(<2)$ & $3(4)$ & $5(6)$ & $8(8)$ \\
\hline $\mathrm{SD}, 2000$ Lux & $0(<2)$ & $2(<2)$ & $3(4)$ & $4(4)$ & $5(8)$ \\
\hline $\mathrm{SD}, 4000$ Lux & $1(<2)$ & $1 \quad(<2)$ & $3(4)$ & $4(6)$ & $8(8)$ \\
\hline
\end{tabular}

zoidogenesis the growth curves (Fig. 8) level off and at the end the macrothallus disintegrates by intense sporulation. Under ID $(16: \overline{8})$ conditions the time span 'necessary for the preparation of zoidogenesis' varies from about 1 week at $20^{\circ} \mathrm{C}$ and 4 weeks at $16{ }^{\circ} \mathrm{C}$ to about 13 weeks at $4{ }^{\circ} \mathrm{C}$ (cf. Table 1 ); this conveys to the $16{ }^{\circ} \mathrm{C}$ macrothallus - notwithstanding a more rapid growth rate - a maximum length of about $100 \mathrm{~mm}$ after ca 5 weeks, while the $4{ }^{\circ} \mathrm{C}$ macrothallus reached a maximum length of more than 300-400 mm after more than 13 weeks of slower growth in one experiment (Fig. 8). It is not a sufficiently large macrothallus size which determines the onset of zoidogenesis, as macrothalli differing one order of magnitude in length but having about the same age, start zoidogenesis at about the same time when grown under the same temperature and day-length conditions (Table 1). Such conspicuous differences in size were obtained by culturing, under identical conditions, either a congregation of thalli in $2 \frac{1 / 2}{\mathrm{~cm}} \times 2 \frac{1 / 2}{\mathrm{~cm}}$ glass square in a Petri dish, or one separate macrothallus in a Petri dish of the same size. In the latter case, $8^{\circ} \mathrm{LD}, 2000$ Lux, a ribbon-like macrothallus of $62 \mathrm{~cm}$ was obtained, and in the former case, under comparable conditions a ribbon-like macrothallus of maximally $8 \mathrm{~cm}$ was harvested.
It seems likely that lack of competition for space and nutrients allows such a much larger (longer as well as broader) plant to develop separately in a Petri dish. Presumably the same factors, apart from temperature, play a role in nature in determining the size of the macrothallus. Such large $(62 \mathrm{~cm})$ macrothalli do not fit the description of Desmotrichum undulatum but those of Punctaria latifolia Grev. (cf. Hauck, 1885; Hamel, 1937; Kylin, 1947; Rosenvinge and Lund, 1947; Taylor, 1957; Zinova, 1967; Rueness, 1977, D. undulatum as Punctaria tenuissima [C. Ag.] Grev.). Except for the much larger size, the occurrence of fascicles of hairs on the lamina is often considered characteristic of $P$. latifolia; while D. undulatum is considered to bear only single hairs and mainly marginal hairs. In our cultures all these features were realized. A delicate texture, and green discoloration after drying has sometimes also been mentioned as being characteristic of $P$. latifolia; these features are also exhibited by our material. A thallus-thickness of 4 or more cell layers is considered characteristic of Punctaria, 2-4 layers of $D$. undulatum. The proximal parts of older blades in our cultures (even 'Desmotrichum-like' ones) were observed to be 4- to 6-layered, whereas younger blades or distal parts of older blades were 1 - or 2-layered. Plants with only

Table 2. 'Wax and wane of Desmotrichum undulatum/Punctaria latifolia on Zostera; Beaufort, North Carolina, USA (Based on Brauner, 1975). Thin bar: rare; thick bar: occasional; low hatching: common; high hatching: frequent; p: plurilocular zoidangia

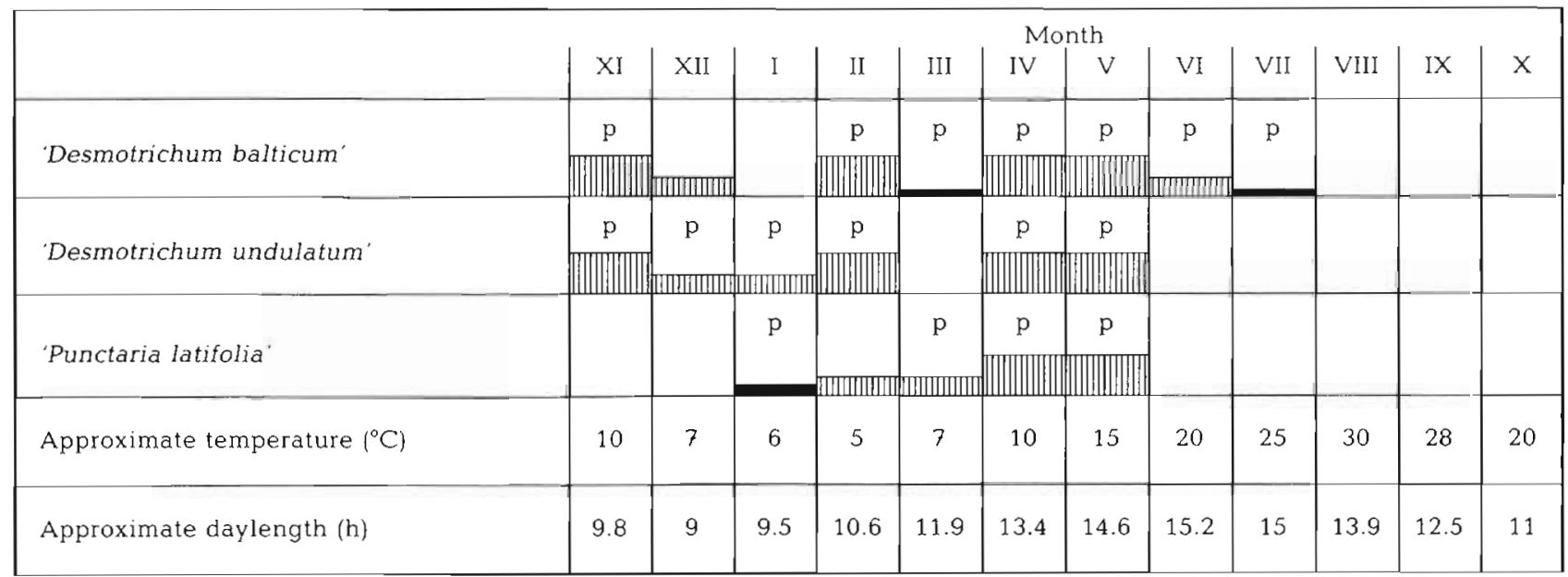


plurilocular, or plurilocular and unilocular zoidangia were described for both species (cf. Reinke, 1889; Hamel, 1937; Rosenvinge and Lund, 1947). In our opinion it is no longer possible to separate both species, and consequently also not the genera Punctaria Greville and Desmotrichum Kiitzing (which is typified by Desmotrichum balticum Kütz, 1845). However, a formal dicision whether or not to synonymize Desmotrichum undulatum (J. Ag.) Kütz, with punctaria latifolia (Greville 1830) should be postponed until the results of cuiture studies, starting with 'Punctaria latifolia'-like plants in nature (long and broad, pluristratose blades), become available

In previous culture studies on Punctaria latifolia (Sauvageau, 1929; Dangeard, 1963; Clayton and Ducker, 1970), plurizoids (in plants with unilocular zoidangia, unizoids) grew into microthalli bearing small macrothalli similar to those in our cultures. In these previous studies the influence of environmental conditions was not investigated.

Apart from temperature, day length affects the onset of zoidogenesis, short day lengths promoting an earlier onset than long day lengths (Fig. 8; Table 1). Table 1 suggests that it is not a small daily light dose which advances the onset of zoidogenesis. Apparently, a combination of low temperatures $\left(4^{\circ}-12{ }^{\circ} \mathrm{C}\right)$ and long day lengths promotes the formation of conspicuous macrothalli. Consequently one would expect the appearance of conspicuous macrothalli in nature during spring. Indeed, the distribution data available (Fig. 10) show that, over most of its range, Desmotrichum undulatum/Punctaria latifolia occurred in early and late spring and disappeared in the beginning of summer. Only in the northern part of its range has it been found exclusively in summer; possibly, this fact reflects not only the occurrence of the species, but also the preferred season in which phycologists visit these regions. Even at its southernmost known boundary the species was still found in June (North Carolina, USA; West-Mediterranean Sea). Few precise data are available about the 'wax and wane', of $P$. latifolia in nature. In protected, shallow waters near Beaufort, North Carolina (USA) (the southernmost known limit of $D$. undulatum/ $P$. latifolia along US East coast) the species is quite common as epiphyte on Zostera and its 'wax and wane' have been followed by Brauner (1975). The water temperature ranges from $3{ }^{\circ} \mathrm{C}$ in winter to $30^{\circ} \mathrm{C}$ in summer (which equals about the range of our experimental conditions); daily temperature changes of $10.5^{\circ} \mathrm{C}$ may occur. Heavy rains may cause the salinity to decrease to $6 \% \mathrm{~S}$. Particularly the 'D. undulatum'-form is often recorded from comparable, protected lagoonal and estuarine habitats, but it also occurs (often as epiphyte) along open coasts in low littoral rock pools and in the upper sublittoral.
The 'waxand wane' of the 'Puactaria latifolia-expression' (large blades), the 'Desmotrichum undulatumexpression' (small, narrow blades) and the 'D. balticum-expression' (uniseriate macrothalli) are summarized in Table 2. These data are clearly in accordance with the hypothesis outlined above, namely that macrothalli may be expected in spring. Moreover, the narrower seasonal range of the large blades ('P. latifolia) in comparison with the small blades ( $D$. undulatum ( and even more so with the uniseriate macrothalli (' $D$. balticum) is in accordance with our culture results.

The maximum summer temperature at Beaufort (ca $30^{\circ} \mathrm{C}$ ) is very near the upper temperature limit (between $30^{\circ}$ and $35^{\circ} \mathrm{C}$ ) which proved lethal to microthalli of this species in our cultures; hence it is likely that the southern limit of this species along the US East coast of North America is determined by the high summer temperatures attained in the protected estuarine and lagoonal waters, which are characteristic for the coasts of the Carolinas (cf. van den Hoek, 1975). Comparable extreme, annual temperature ranges occur in a shallow Mediterranean French lagoon where the Desmotrichum undulatum-expression has been encountered (Petit and Aleem, 1952) and in shallow water along the north coast of the Black Sea $\left(0^{\circ}-29^{\circ} \mathrm{C}\right.$; Zenkevič, 1963); here, the upper temperature limit (ca $30^{\circ}-35^{\circ} \mathrm{C}$ ) for cultured $D$. undulatum is not yet exceeded.

If the other records from open Mediterranean coasts represent the southernmost geographic limit, this limit cannot be due to the maximum summer temperature tolerable by microthalli, since summer temperatures here do not exceed about $25^{\circ} \mathrm{C}$. More likely, a temperature sufficiently low to permit the development of conspicuous macrothalli in spring seems to determine this limit (ca $12^{\circ}-15^{\circ} \mathrm{C}$ ) in spring in the Mediterranean Sea.

In Schneider's 1976 survey of benthic marine algae inhabiting scattered offshore reefs on the continental shelf directly south of Beaufort, North Carolina, Desmotrichum undulatum and Punctaria latifolia are lacking. It is likely that the prevailing winter temperatures $\left(10^{\circ}-22^{\circ} \mathrm{C}\right)$ are too high for the development of macrothalli. The reefs are inhabited by an impoverished tropical, Caribbean flora with several endemics and few temperate species (see also van den Hoek, 1975).

In the northern parts of its geographic range Desmotrichum undulatum/Punctaria latifolia, has been encountered in summer, at maximum temperatures of ca $10^{\circ} \mathrm{C}$ (in open-coast locations). It is therefore likely that the northern limit of this species is determined by a summer temperature sufficiently high to permit the development and fruiting of macrothalli during the brief summer. The northernmost station along East 


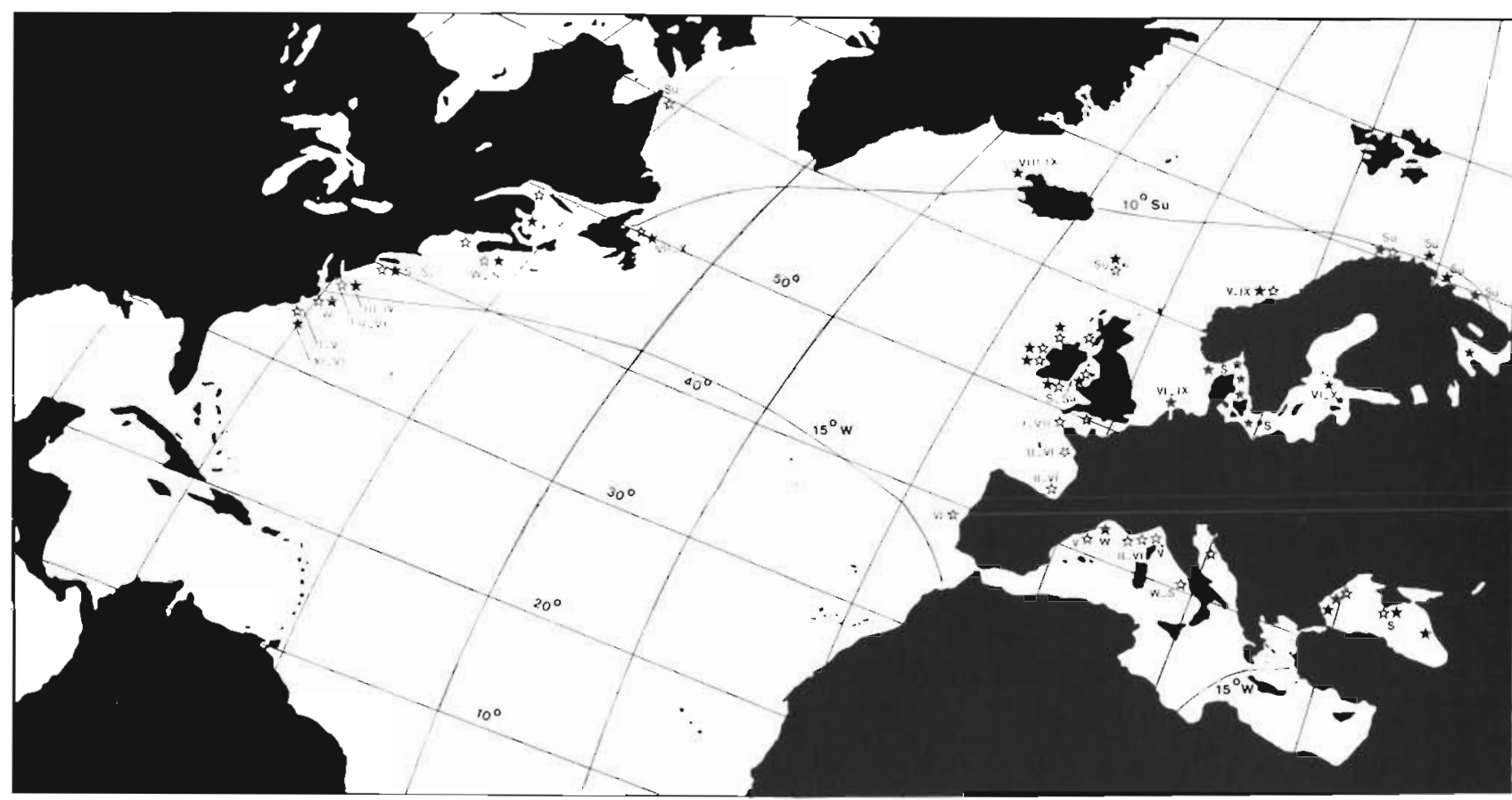

Fig. 10. Desmotrichum undulatum. $\star$ as Desmotrichum undulatum; is as P. latifolia. I, II, etc.: months in which the species was encountered. S: spring, Su: summer, W: winter. Distribution area bordered roughly by $10^{\circ} \mathrm{C}$-summer-isotherm to the north, $15^{\circ} \mathrm{C}$ winter-isotherm to the south. Data from Harvey, 1846-51; Hauck, 1885; Cotton, 1912; Printz, 1926; Sauvageau, 1929; Knight and Parke, 1930-31; Boudouresque and Perret, 1937; Hamel, 1937; Feldmann, 1937; Rosenvinge and Lund, 1947; Zinova, 1953, 1967; Feldmann, 1954; Funk, 1955; Taylor, 1957; Wilce, 1959; Jaasund, 1965; Ardré, 1970; Rhodes, 1970b; Orris and Taylor, 1973; Brauner, 1975; South, 1975; Hooper and South, 1977; Munda, 1977, 1978; Guiry, 1978; Searles and Schneider, 1978 ; Lee, 1980

American coasts is Hebron Fjord, Labrador (Wilce, 1959 , as $D$. undulatum). In such fjords the summer temperature of surface waters may rise to $10^{\circ} \mathrm{C}$. The winter temperature is mostly near $-1.7^{\circ} \mathrm{C}$.

At the southem boundary, the warm period unfavourable for the development of conspicuous macrothalli (summer, autumn) is probably passed in the form of a sequence of intensely reproducing microthallus generations bearing ephemeral diminutive macrothalli. No culture data are available for predicting the method of hibernation at the northern boundary, as the lowest temperature investigated in our experiments was $4{ }^{\circ} \mathrm{C}$. Possibly non-fertile microthalli with and without non-fertile macrothalli survive the low temperatures (around $0{ }^{\circ} \mathrm{C}$ ) and, in arctic northern Europe, the polar night. In the brackish Bothnian Golf (with salinities as low as $5 \%$ S) old macrothallusribbons were seen in March on leaves of Potamogeton pectinatus where they had survived under the ice during winter (Ravanko, 1975, as D. undulatum). It is interesting to note that in Desmotrichum undulatum/ Punctaria latifolia on the one hand and Scytosiphon lomentaria, Petalonia fascia (for review see Wynne and Loiseaux, 1976) and the rhodophyte Dumontia contorta (Gmelin) Rupr. (= D. incrassata) (Rietema and Klein, 1981) on the other, the development of a spring generation of macrothalli from microthalli is directed in two different ways: in $D$. undulatum/P. latifolia the development of macrothalli is initiated under a wide range of temperature conditions, as well as under longday and short-day conditions; however, the increasingly rapid onset and progression of zoidogenesis with increasing temperature at the end of spring arrests macrothallus development. In contrast, in Scytosiphon, Petalonia and Dumontia the initiation of macrothallus development from microthalli is triggered by short-day conditions. It is likely that in these 3 species reproduction also terminates the life span of macrothalli. Possibly, temperature acts as controlling factor, as in $D$. undulatum/P. latifolia. In the warm-temperate Ihodophyte Acrosymphyton purpuriferum growth and reproductive maturation of the macrothallus (the gametophyte) are promoted by increasing summer temperatures. Reproduction terminates the life span of the macrothallus at the end of summer (as in $D$. undulatum $/ P$. latifolia at the end of spring). Initiation of macrothallus development from the perennial microthallus through the formation of tetraspore is promoted by lower winter-to-spring temperatures but, in addition, it is more precisely timed by short-day conditions (Breeman, 1979).

In summary, seasonal temperature changes seem to control the seasonal succession of microthalli and macrothalli in the above-mentioned 5 species. Macrothalli 
of 4 of these species are all spring annuals (Desmotrichum undulatum/Punctaria latifolia, Scytosiphon lomentaria, Dumontia contorta, Petalonia fascia); one is a summer annual (Acrosymphyton purpuriferum). In the four latter species initiation of macrothalli development is more precisely timed by short-day conditions than in $D$. undulatum/P. latifolia.

\section{LITERATURE CITED}

Ardré, F. (1970). Contribution à l'étude des algues marines du Portugal I-La Flore. Port. Acta biol. (B) 10: 1-423

Boudouresque, C.-F., Perret, M. (1977). Inventaire de la flore marine de Corse (Méditerranée), (Bibliotheca phycologica 25) J. Cramer, Vaduz

Brauner, J. F. (1975). Seasonality of epiphytic algae on Zostera marina at Beaufort, North Carolina. Nova Hedwigia 26: $125-133$

Breeman, A. M. (1979). The life history and its environmental regulation in the subtidal red alga Acrosymphyton purpuriferum (J. Ag.) Sjöst. Ph. D. thesis, University Groningen

Clayton, M. N., Ducker, S. C. (1970). The life history of Punctaria latifolia Greville (Phaeophyta) in Southern Australia. Aust. J. Bot. 18: 293-300

Cotton, A. D. (1912). Clare Island survey, Part 15, marine algae. Proc. Irish Acad 31:1-178

Dangeard, P. (1963). Sur le développement de ,Punctaria latifolia Greville récolté dans le Bassin d'Arcachon Botaniste 46: 205-224

Feldmann, J. (1937). Les algues marines de la Côte des Albères, I-III Rev. Algol 9: 141-331

Feldmann, J. (1954). Inventaire de la flore marine de Roscoff. Algues, champignons, lichens et spermatophytes. Trav Stn biol. Roscoff, (Suppl.) 6: 1-152

Funk, G. (1955). Beiträge zur Kenntnis der Meeresalgen von Neapel. Pubbl. Staz. zool. Napoli 25 (Suppl.): 1-178

Greville, R. K. (1830). Algae britannicae, MacLachlan and Stewart, Edinburgh

Guiry, M. D. (1978). A consensus and bibliography of Irish seaweeds, J. Cramer, Vaduz (Bibliotheca phycologia 44)

Hamel, G. (1937). Phéophycées de France, Fasc. IJI, Paris, pp. $177-240$

Harvey, W. H. (1846-51). Phycologia britannica, Vol. I, Reeve and Benham, London

Hauck, F. (1885). Die Meeresalgen Deutschlands und Oesterreichs, 2. Aufl, Kummen, Leipzig, (Rabenhorsts Kryptogamen Flora, 2. Band)

Hoek, C., van den (1975). Phytogeographic provinces along the coasts of the northern Atlantic Ocean. Phycologia 14 $317-330$

Hoek, C., van den (1979). The phytogeography of Cladophora (Chlorophyceae) in the northern Atlantic Ocean, in comparison to that of other benthic algal species. Helgoländer wiss. Meeresunters. 32: 374-393

Hooper, R., South, G. R. (1977). Additions to the benthic marine algal flora of Newfoundland III, with observations on species new to eastern Canada and North America. Naturaliste can. 104: 383-394

Jaasund, E. (1965). Aspects of the marine algal vegetation of North Norway. Botanica gothoburg. IV, 1-174

Knight, M., Parke, M. W. (1930-31). Manx Algae. Proc. Trans. Liverpool biol. Soc. 30
Kützing, F. T (1845). Phycologia germanica, F. T Kützing, Nordhausen

Kylin, H. (1933). Uber die Entwicklungsgeschichte der Phaeophyceen. Acta Univ. Lund.; N. F. (Avd. 2) 29: 1-102

Kylin, H. (1947). Die Phaeophyceeen der schwedischen Westküste. Acta Univ. Lund., N. F. (Avd. 2) 43 (4): 1-99

Lee, R. K. S. (1980). A catalogue to the marine algae of the Canadian Arctic. National Museums of Canada, National Museum of National Sciences, Ottawa. Publications in Botany, No. 9: 1-82

Loiseaux, S. (1969). Sur une espèce de Myriotrichia obtenue en culture à partir de zoides d'Hecatonema maculans Sauv. Phycologia 8: 11-15

Munda, I. (1977). The benthic algal vegetation of the Island of Grimsey (Eyafjaroarsýsla, North Iceland). Bull. Res. Inst. Neori As 25: 1-69

Munda, I. M. (1978). Survey of the benthic algal vegetation of the Dýrafjördur, Northwest Iceland. Nova Hedwigia 29: $281-403$

Orris, P. K., Taylor, J. E. (1973). A floristic and ecological survey. The benthic macro-algae of Rehoboth Bay, Delaware. Botanica Mar 16: 180-192

Petit, G.. Aleem, A. A. (1952). Caractéristiques et évolution d'un étang des Pyrénées Orientales. C. r. hebd. Séanc. Acad. Sci., Paris 235: 632-634

Printz, H. (1926). Die Algenvegetation des Trondhjemsfjordes. Skr. norske VidenskAkad. (Mat. Naturv. Kl.) 5: $1-274$

Provasoli, L. (1968). Media and prospects for the cultivation of marine algae. In: Watanabe, A., Hattori, A. (eds) Cultures and collection of algae (Proceedings of the U.S.-Japan Conference, Hakone, Sept. 1966). Japan, Society of Plant Physiology, Tokyo, pp. 63-75

Ravanko, O. (1975). Studies on the development of the brown alga Desmotrichum undulatum in nature and culture Memo. Soc. Fauna Flora fenn. 51: 19-23

Reinke, J. (1889). Atlas deutscher Meeresalgen, Band 1, Paul Parey, Berlin

Rhodes, R. (1970a). Relation of temperature to development of the macrothallus of Desmotrichum undulatum. J. Phycol. 6: $312-314$

Rhodes, R. (1970b). Seasonal occurrence of marine algae on an oyster reef in Burton's Bay, Virginia. Chesapeake Sci. 11: $61-71$

Rietema, H., Klein, A. W. O. (1981). Environmental control of the life cycle of Dumontia contorta (Rhodophyta) kept in culture. Mar. Ecol. Prog. Ser. 4: 23-29

Rosenvinge, L. K., Lund, S. (1947). The marine algae of Denmark, vol. II. Phaeophyceae III. danske Vidensk. Selsk. Biol. Skr. IV (5) 1-99

Rueness, J. (1977). Norsk Algeflora, Universitetsforlaget, Oslo

Sauvageau, C. (1929). Sur le développement de quelques Phéosporées. Bull. Stn biol. Arcachon 26: 253-420

Schneider, C. W. (1976). Spatial and temporal distributions of benthic marine algae on the continental shelf of the Carolinas. Bull. mar. Sci. 26: 133-151

Searles, R. B., Schneider, C. W. (1978). A checklist and bibliography of North Carolina Seaweeds. Botanica Mar. 21: 99-108

South, G. R. (1975). Common seaweeds of Newfoundland, Oxen Pond Botanic Park \& Marine Research Laboratory, Memorial University Newfoundland, Newfoundland

Taylor, W. R. (1957). Marine algae of the northeastern coast of North America, University of Michigan Press, Ann Arbor

Wilce, R. T (1959). The marine algae of the Labrador Penninsula and Northwest Newfoundland (Ecology and distribution). Bull. natn. Mus. Can. 158: 1-81 
Wynne, M. J., Loiseaux, S. (1976). Recent advances in life history studies of the Phaeophyta. Phycologia 15: 435-452

Zenkevicic, L. A. (1963). Biologia more'j SSSR. Izd. Akad. Nauk. SSSR, Moskva
Zinova, A. D. (1953). Opredel 'itel' burych vodorosl 'ej severnych more'j SSSR, Izd. Akad. Nauk. SSSR, Moskva

Zinova, A. D. (1967). Opredel 'itel' zel'enych burych i Krasnych vodoroslei juznych more'j SSSR, 'Nauka', Moskva

This paper was presented by Professor C. van den Hoek; it was accepted for printing on October 17, 1980 